\section{Cattle use of perennial streams and associated riparian areas on a northeastern Oregon landscape}

\author{
D.E. Johnson, L.L. Larson, K.D. Wilson, P.E. Clark, J. Williams, and M. Louhaichi
}

\begin{abstract}
Stream and riparian health is a major concern for state and federal land management agencies that are charged with oversight of extensive land holdings in the mountain west of the United States. Several federal agencies in the 1980s and 1990s determined that livestock grazing had adversely impacted a majority of federal lands in this region. In response, management was changed on grazing allotments to focus on stream system health. Recent advanced global positioning system (GPS) logging capabilities, both accuracy and frequency/ duration of logging, coupled with rapidly developing geographic information system (GIS) analytical capabilities allowed evaluation of livestock use of streams and riparian zones on mountain rangelands. This study was undertaken to clarify spatiotemporal characteristics of cattle use of perennial streams and associated riparian areas under current US Forest Service (USFS) management and to suggest managerial strategies with the potential to maintain or improve riverine environments. We initiated a five year study in 2008 to evaluate the use by cattle of $30 \mathrm{~m}(98.4 \mathrm{ft})$ and $60 \mathrm{~m}(196.9 \mathrm{ft})$ buffers on permanent streams on three extensive study sites in northeastern Oregon. The three study sites cover 43,972 ha $(108,700 \mathrm{ac})$ within a broader region $120 \mathrm{~km}$ (74.5 mi) north-south by $50 \mathrm{~km}$ (31 mi) east-west. Ten randomly selected cows from herds grazing each site were fitted with GPS collars that recorded position, date, and time at approximately five minute intervals throughout the grazing season. Nearly $3,750,000$ cow positions were collected on the allotments during the study. The relative occupancy of cattle in buffers along both sides of perennial streams were determined on an annual and monthly basis by site. Each position was tagged with the date and time of occurrence. Relative use within $30 \mathrm{~m}$ of the stream varied substantially from site to site $(0.74 \%$ to $2.54 \%$ ), month to month $(0.00 \%$ to $5.21 \%)$, and year to year ( $0.86 \%$ to $2.13 \%)$. In some months, GPS data indicated that watering was nearly exclusive from streams. In other months, stream use was low or nil, and watering was from water developments, small springs, seeps, puddles, or other source. Cattle preferred to access streams at specific locations where streambank slope, the lack of physical obstructions, and solid footing facilitated water access.
\end{abstract}

Key words: cattle use pattern — GPS tracking collars — grazing management — land use — spatial analysis - site preference

Land managers in the western United States manage timber, range, water, recreation, and wildlife resources for multiple uses and sustained yields of ecosystems, products, and services. Stream and riparian health is a major emphasis on these landscapes, and this topic has received focus over the last 40 years. In the 1980s and early 1990s, several federal agencies, including the US Forest Service (USFS), Bureau of Land Management (BLM), and the US Environmental Protection Agency (USEPA) et al. 1983; Gillen et al. 1984; Harris et al. 2002), but much remains to be learned about the specifics of stream and riparian use.

Quantification of livestock use of streams and riparian areas on extensive landscapes using direct observation is difficult because observation is not continuous and topographic, shrub, and tree cover limits visual observation of animals. With the advent of global positioning system (GPS) technology, this hurdle has largely been overcome. There are now opportunities to examine stream/livestock interactions, intensity of use of the landscapes via geographic clustering or "heat maps," and the effectiveness of interventions, such as the location of water or the placement of salt/minerals (Ganskopp 2001; Bailey et al. 2008). Our five year study was designed to evaluate the relative use by cattle of permanent streams and associated riparian areas on three USFS allotments in northeastern Oregon.

We focused on the following questions:

1. What is the intensity of cattle use of permanent streams and associated riparian zones on operational USFS grazing allotments?

2. What is the geographic pattern of cattle use on streams and stream buffer areas?

3. How does this use change throughout the season and across years?

\section{Materials and Methods}

Site Description. This study was conducted on three allotments of the Wallowa Whitman National Forest in Baker, Union, and Wallowa counties, Oregon. The study sites are extensive, covering $439.9 \mathrm{~km}^{2}$ $\left(169.8 \mathrm{mi}^{2}\right)$ (Site $1=217.6 \mathrm{~km}^{2}\left[84 \mathrm{mi}^{2}\right]$, Site $2=119.9 \mathrm{~km}^{2}$ [46.3 $\left.\mathrm{mi}^{2}\right]$, and Site 3 $=102.4 \mathrm{~km}^{2}$ [39.5 $\left.\mathrm{mi}^{2}\right]$ ). Because the sites are spread over an area of approximately $120 \mathrm{~km}$ (974.5 $\mathrm{mi})$ by $50 \mathrm{~km}$ (31 mi), in

Douglas E. Johnson is a professor emeritus and Larry $L$. Larson is a retired professor in the Department of Animal and Rangeland Sciences, Oregon State University, Corvallis, Oregon. Kerry D. Wilson is a soil conservationist for the USDA Natural Resources Conservation Service (NRCS) in Pendleton, Oregon. Patrick E. Clark is a rangeland scientist for the USDA Agricultural Research Service (ARS) in Boise, Idaho. John Williams is an associate professor in the Department of Animal and Rangeland Sciences, Oregon State University, Corvallis, Oregon. Mounir Louhaichi is a principal rangeland scientist for the International Center for Agricultural Research in Dry Areas (ICARDA), Amman, Jordan. 
a mountainous environment, the elevation of the allotments varied widely (from $733 \mathrm{~m}$ [2,405 ft] to $2,454 \mathrm{~m}$ [8,051 ft]); however, all sites are found within the Blue Mountain Ecological Province of Oregon (Anderson et al. 1998).

The combined study region receives approximately $570 \mathrm{~mm}$ (22.4 in) of precipitation annually. Over half of this amount comes during the period between November and March. As would be expected, annual precipitation is greatest at the highest elevations; thus the most arid areas $\left(472 \mathrm{~mm} \mathrm{y}^{-1}\right.$ [18.6 in $\left.\mathrm{yr}^{-1}\right]$ ) are in the lower reaches of creeks draining into the Snake River, and areas with the greatest precipitation (approximately $1,435 \mathrm{~mm} \mathrm{y}^{-1}\left[56.5 \mathrm{in} \mathrm{yr}^{-1}\right]$ ) are found in the Wallowa Mountains north of Baker, Oregon (Prism Climate Group 2014). The elevation range of each study area and the associated 30 -year average annual precipitation across each site as provided by the Prism Climate Group (2014) are given in table 1.

Approximately a third of the area is grassland with the remainder being coniferous forest land, which transitions with increasing elevation and precipitation from ponderosa pine (Pinus ponderosa Lawson \& C. Lawson) to Douglas fir (Pseudotsuga menziesii [Mirb.] Franco) and grand fir (Abies grandis Douglas ex D. Don) (Anderson et al. 1998). Idaho fescue (Festuca idahoensis Elmer) and bluebunch wheatgrass (Pseudoroegneria spicata [Pursh] Á. Löve) are dominant grass species. However, Kentucky bluegrass (Poa pratensis L.), Canada bluegrass (Poa compressa L.), bulbous bluegrass (Poa bulbosa L.), and Sandberg bluegrass (Poa secunda J. Presl) are also widespread. In forested communities, elk sedge (Carex garberi Fernald) and pinegrass (Calamagrostis rubescens Buckley) are common components of the herbaceous strata. Specific grassland and forest community types common to this region are described in Hall (1973).

Land use in this area is a mixture of timber production, livestock grazing, wildlife habitat, recreation, and watershed services. Population density in the region is low with no large cities or towns. The USFS is the primary land managing entity (USDA 2006). More detailed information on study sites can be found in Johnson et al. (2012).

Cattle Herds and Tracking Collars. Ten mature cows from herds grazing each study allotment were randomly selected each spring between 2008 and 2012 and fitted with a Clark ATS GPS collar (Clark et al.
2006) to record the date, time, and position at approximately five minute intervals. These cattle have been grazing their respective study sites for years and have experience with the landscape, environment, and managerial operations in place. After collaring, all cattle, including collared animals, were transported to their respective study areas where they grazed with herd mates in accordance with ranch and USFS grazing management plans. Some USFS allotments (study areas) have private land inclusions, adjacent private ground, or other federal lease lands that are contiguous with allotments and are also grazed by these herds during the summer grazing season. Thus, collared cattle may go off the allotment for short periods, then return. Livestock turn-out dates vary between study areas from April to June and within an allotment also slightly from year to year. At the end of the grazing season (October or November), cattle were gathered and returned to their home ranches, where GPS collars were removed and the data were downloaded.

During the grazing season, all animals in the herd were treated similarly. Herd size varies from site to site and somewhat from year to year. We assume that the activity, movement, and ecological site selection of collared animals is representative of other cattle in the herd. The number of collared cattle positions gathered each year and month for each of the study sites are given in table 2 .

Data Quality, Handling, and Statistical Analysis. Clark ATS GPS collars are programmed to activate and begin to search for satellites at five minute intervals; thus, the recorded interval is somewhat longer (15 to 30 seconds) than five minutes. In addition, if the collar cannot obtain a fix in a set amount of time, the collar is programmed to shut down and wait for the next collection period. In a test of 1,194 days of data collection during 2008 on Oregon Site 1, collars logged an average of 269 positions $\mathrm{d}^{-1}$, or a point every 5.35 minutes.

The number of positions collected during the month varies because collars can fail as they progress through the season. In addition, as collars age their reliability is somewhat decreased, and since cows can move onto or off the allotments in midmonth, the number of GPS positions in a given time period changes between years (table 2). Table 2 provides the mean number of GPS positions collected each month and the number of collars collecting data.

Under optimal, open-sky conditions, Clark ATS Collars had a 95\% circular error probability (CEP) of $6.3 \mathrm{~m}(20.7 \mathrm{ft})$ without Wide Area Augmentation System (WAAS) correction and $2.7 \mathrm{~m}(8.9 \mathrm{ft})$ with correction (Clark et al. 2006). Positional accuracy of GPS receivers is compromised in complex landscapes with deep canyons or locations without a full $180^{\circ}$ sky view. We tested the Clark ATS collar design under extreme conditions in two canyons of northeastern Oregon. This test evaluated 192 positional fixes while moving at a slow speed. In this situation, there was a mean absolute error of $21.5 \mathrm{~m}$ (70.5 $\mathrm{ft})$ with a standard deviation of $23.7 \mathrm{~m}(77.7$ $\mathrm{ft}$ ). The maximum error was $146 \mathrm{~m}$ (479 ft). Surprisingly, the largest errors were not in the deepest portions of the canyon, suggesting that large errors were the result of multipath or incomplete trilateration.

Stream layer data were obtained and refined from several sources: US Geological Survey (USGS), USFS, and StreamNet (2016). Spatial errors among these data sources were significant enough to require correction for the purposes of this study. Permanent streams were identified by both field visits and paper maps with permanent streams outlined by cooperators. The identified streams were then digitized using both USGS $7.5 \mathrm{~min}$. Digital Raster Graphics (DRG from 1:24,000 maps) and 2009 USDA National Agriculture Imagery Program (NAIP) acquired at a $1 \mathrm{~m}(3.3 \mathrm{ft})$ ground sample distance (GSD) with a horizontal accuracy within $6 \mathrm{~m}(19.7 \mathrm{ft})$ of photo-identifiable ground control points.

Buffers were created at $30 \mathrm{~m}(98.4 \mathrm{ft})$ and $60 \mathrm{~m}(196.9 \mathrm{ft})$ along corrected stream vectors. These buffers were used to count the number of cow GPS positions near the stream and to extract those positions for analysis of timing and duration of use. Data were converted to a percentage basis for clarity. Most of the streams on these mountainous allotments are relatively narrow $(<3$ $\mathrm{m}[<9.8 \mathrm{ft}]$ ) with ascending topography on either side, thus the 0 to $30 \mathrm{~m}$ buffer encompasses most riparian corridor areas.

Experimental Design. Our study is descriptive in nature and was conducted to provide base information about how livestock interact with streams and associated riparian lands on extensive mountainous landscapes. We assumed that the spatiotemporal behav- 
Table 1

Characteristics of the three study allotments used in this investigation.

\begin{tabular}{|c|c|c|c|}
\hline Characteristic & Site 1 & Site 2 & Site 3 \\
\hline Surface area (ha) & 21,759 & 11,990 & 10,237 \\
\hline Elevation range $(\mathrm{m})$ & 1,126 to 2,454 & 952 to 1,699 & 733 to 1,590 \\
\hline 30-year mean precipitation range $(\mathrm{mm})$ in the allotment & 626 to $1,435 *$ & 654 to $997 *$ & 472 to $648 *$ \\
\hline Number of water developments & 44 & 41 & 68 \\
\hline Number of pastures & 11 & 7 & 10 \\
\hline Number of pastures with perennial stream access & 6 & 3 & 7 \\
\hline Number of pastures with no water developments & 1 & 1 & 1 \\
\hline Total length of perennial streams (km) & 39.2 & 24.3 & 27.5 \\
\hline Area of the $60 \mathrm{~m}$ buffer around perennial streams (ha) & $\begin{array}{r}468.3(2.15 \% \\
\text { of allotment) }\end{array}$ & $\begin{array}{r}285.2(2.38 \% \\
\text { of allotment) }\end{array}$ & $\begin{array}{r}341.3(3.33 \% \\
\text { of allotment }\end{array}$ \\
\hline Area of the $60 \mathrm{~m}$ buffer around off-stream water developments (ha) & $\begin{array}{l}49.6(0.23 \% \\
\text { of allotment) }\end{array}$ & $\begin{array}{l}46.2(0.39 \% \\
\text { of allotment) }\end{array}$ & $\begin{array}{r}76.57 \text { (0.74\% } \\
\text { of allotment }\end{array}$ \\
\hline
\end{tabular}

*Source: Prism Climate Group (2014).

\section{Table 2}

Total number of collared cattle positions logged on each of the study sites each month of the study between 2008 and 2012 , and the mean number of collared cattle across years that contributed to the data set. The number of observations vary based on the number of functioning collars and the number of days the cattle were on the allotments (Ganskopp et al. 2000; Johnson and Ganskopp 2008; Liu et al. 2015).

\begin{tabular}{|c|c|c|c|c|c|c|c|}
\hline \multirow[b]{2}{*}{ Site/month } & \multicolumn{5}{|l|}{ Year } & \multirow[b]{2}{*}{ Total } & \multirow{2}{*}{$\begin{array}{l}\text { Mean } \\
\text { number of } \\
\text { cows tracked }\end{array}$} \\
\hline & 2008 & 2009 & 2010 & 2011 & 2012 & & \\
\hline \multicolumn{8}{|l|}{ Site 1} \\
\hline June & 33,325 & 36,642 & NA & 33,507 & 24,346 & 127,820 & 9.0 \\
\hline July & 60,323 & 76,000 & 41,614 & 70,030 & 52,499 & 300,466 & 8.6 \\
\hline Oct. & 11,609 & 24,709 & 11,458 & 15,795 & 3,140 & 66,711 & 6.4 \\
\hline Total & 213,796 & 275,943 & 177,315 & 241,480 & 146,898 & $1,055,432$ & \\
\hline \multicolumn{8}{|l|}{ Site 2} \\
\hline June & 44,810 & 69,091 & 51,434 & 28,026 & 25,692 & 219,053 & 7.0 \\
\hline July & 51,112 & 75,650 & 75,661 & 41,038 & 37,865 & 281,326 & 6.8 \\
\hline Total & 213,151 & 313,019 & 290,102 & 149,024 & 146,607 & $1,111,903$ & \\
\hline \multicolumn{8}{|l|}{ Site 3} \\
\hline Apr. & 37,859 & 7,145 & 24,852 & 27,339 & 19,202 & 116,397 & 8.2 \\
\hline May & 91,360 & 42,321 & 84,638 & 61,201 & 46,619 & 326,139 & 8.6 \\
\hline June & 47,483 & 40,752 & 83,133 & 60,280 & 70,794 & 302,442 & 7.4 \\
\hline July & 38,841 & 41,929 & 77,116 & 56,915 & 49,879 & 264,680 & 7.0 \\
\hline Aug. & 38,634 & 41,199 & 82,410 & 54,901 & 6,912 & 224,056 & 5.4 \\
\hline Sept. & 22,540 & 40,085 & 75,561 & 55,936 & 5,461 & 199,583 & 5.2 \\
\hline Oct. & 0 & 31,470 & 70,061 & 38,463 & 6,196 & 146,190 & 5.5 \\
\hline Total & 276,717 & 244,901 & 497,771 & 355,035 & 205,063 & $1,579,487$ & \\
\hline Grand total & 703,664 & 833,863 & 965,188 & 745,539 & 498,568 & $3,746,822$ & \\
\hline
\end{tabular}


iors of collared cattle are representative of their subgroup, which usually consists of 5 to 15 herd mates, as well as the entire herd. The study sites are representative of the region with its combined federal/private collaborative managerial systems. However, each study area is unique and has an individualized grazing management plan that is approved by USFS range conservationists and the forest supervisor.

Comparisons between sites and years for various parameters were evaluated using multifactor analysis of variance (MANOVA) with an a priori significance level of 0.05 . If a significant difference were found, means were identified as significantly different with Fisher's Protected Least Significant Difference (LSD) procedure. With this method, there is a $5 \%$ risk of calling each pair of means significantly different when there is no actual difference. Comparisons were planned for the extent of collared cow occupancy near streams, both relative intensity of use and linear extent. Also compared were occupancy within stream/riparian buffers with occupancy at water developments by site, and within sites by month and year. Frequency of cattle positions in $30 \mathrm{~m}(98.4$ $\mathrm{ft})$ and $60 \mathrm{~m}(196.9 \mathrm{ft})$ buffers around each perennial stream on the three study areas were also examined in a geographic information systems (GIS) context using topographic (elevation, slope, and aspect), road, vegetative/soil, and prior land use activities, as well as satellite and aerial image data to identify factors that contribute to use or disuse by season and site. Frequent field visits verified that factors were correctly interpreted.

We also geographically clustered cattle positions (calculated density values from the GPS cattle points), on both a 1 ha $(2.5$ ac) grid cell basis for general landscape occupancy or on a $30 \mathrm{~m}(98.4 \mathrm{ft})$ basis for stream/riparian use. In addition, isolines representing collared cattle occupancy at specific durations were generated by specifying the cell size (30 or $100 \mathrm{~m}$ [328.1 ft]) and the search radius at three times the cell size. No Gaussian smoothing was applied during this operation. These procedures generated "heat maps," which identified areas of none or light versus heavier use on a standardized count per hectare basis. The proportion of the stream occupied at various levels of occupancy was evaluated within sites across years with multiple regression analysis in Statgraphics Centurion XVI
(2010). Landscape occupancy is similar to home range analysis in its application and is often used by wildlife researchers (Burt 1943; Powel 1987; Plowman et al. 2006; Kie et al 2010). We have applied it in this situation with the caveat that domestic stock are not entirely free to travel where they like and are constrained to pastures within which they exercise selection.

Examination of USFS Allotment Grazing Plans and interviews with range riders and ranchers were also conducted to clarify the recorded pattern of collared cattle movement and responses observed. For example, an obvious, relatively small area of an accessible portion of one allotment was not used by collared cattle and we could see no reason why the area would not be used. When we queried the rancher about the location, he indicated that there had been a fire at that location and they were asked by the USFS range conservationist not to graze there.

\section{Results and Discussion}

When viewing the cattle GPS data sets in a geographical context, it was apparent that cattle used the bulk of the surface area of the allotment and that certain locations and travel routes were preferred. It was also obvious that cow position and movement was the result of managerial objectives, ranch/ USFS grazing management plans, prior logging activity, topography, phenology of vegetation (seasonal development and maturation of vegetation), water distribution, and a host of other natural and anthropogenic factors. Many authors have addressed factors controlling livestock distribution (Cook 1966; Bryant et al. 1982; Ganskopp and Vavra 1987; Coughenour 1991; Bailey et al. 1996; Harris 2002; Kluever et al. 2009; Wilson 2010). Perimeter and internal fencing was obviously important because these allotments have been subdivided to implement rotational grazing strategies, although fencing is neither complete nor entirely effective between pastures. Also important was the location where livestock enter allotments because it influenced routes that cattle used as they disperse across the landscape and progressively upward onto higher elevation rangelands. Point of entry was used by managers in conjunction with topography and water to alter landscape grazing patterns from year to year.

Herding and movement of cattle by ranchers and range riders also had a major influence on use pattern, and we could see the dates and times when animals were herded from place to place during the grazing season. This movement was designed to maintain the flow of cattle through the allotment in accordance with the prescribed USFS grazing plan and reaffirmed that these are controlled landscapes with the primary objectives of sustained harvest of forage by dispersing livestock, which prevents over-use of the vegetation resources and ecosystem degradation.

Overall Pattern of Stream/Riparian Buffer Use by Collared Cattle. As would be expected, not all permanent streams were visited by collared cattle during every month and year of the study (table 3). Use patterns depended on the annual rotation of livestock, management objectives, and allotment grazing pattern. For example, on Site 1, between 1 and 10 of the 11 permanent streams had no collared cattle occupancy (within $60 \mathrm{~m}$ [196.9 ft] of the thalweg) during that grazing year across the five years of the study (table $3)$. On an annual (yearly) basis, these differences were highly significant $(p<0.0001)$ with 2009 having the most streams used (10) and 2010 and 2012 the least (1 and 3, respectively). We should note that Site 1 has the longest total length of permanent stream of all the study sites (table 1), yet because of the size of the allotment, the $60 \mathrm{~m}$ buffered area along its streams amounted to 468.3 ha $(1,157 \mathrm{ac})$ or $2.15 \%$ of the total allotment area, which is proportionately less than the other sites (table 1). The number of stream/ riparian zones visited on a monthly basis also showed substantial variation (table 3 ), which was largely dependent on which portions of the allotment were being grazed and how animals were moved across the landscape. This is principally based on management decisions, which determine the timing and sequence of pasture use.

Site 2 contained only a single long permanent creek, which was utilized every year. It was visited in most months of the grazing season, but in June and July of 2009, 2011, and 2012 and June of 2010 the $60 \mathrm{~m}$ (196.9 $\mathrm{ft}$ ) buffer along the stream was not occupied by collared cattle (table 3). During these periods cattle relied on off-stream water developments, small natural springs, puddles, seeps, and dew/vegetation succulence for water. The stream did have heavier use at higher elevations $(\approx 1,400 \mathrm{~m}[4,593 \mathrm{ft}])$ where it passed through areas that had been selectively (commercial and noncommer- 
Table 3

Use of a $60 \mathrm{~m}$ buffer on either side of perennial streams on each of the study areas by year and month. Site 2 has only one very long permanent stream in the allotment. In April and May on Sites 1 and 2, June of 2010 on Site 1, and October of 2008 on Site 3 collared livestock were not present on the allotments.

\begin{tabular}{|c|c|c|c|c|c|c|c|c|c|}
\hline \multirow[b]{2}{*}{ Site/year } & \multirow{2}{*}{$\begin{array}{l}\text { Number of permanent } \\
\text { streams visited } \\
\text { (season long) }\end{array}$} & \multirow{2}{*}{$\begin{array}{l}\text { Number of streams } \\
\text { not visited } \\
\text { (season long) }\end{array}$} & \multicolumn{7}{|c|}{$\begin{array}{l}\text { Number of streams visited by collared cattle } \\
\text { ( } 60 \mathrm{~m} \text { buffer on both sides of streams) }\end{array}$} \\
\hline & & & Apr. & May & June & July & Aug. & Sept. & Oct. \\
\hline 2008 & 4 & 7 & - & - & 1 & 3 & 2 & 2 & 3 \\
\hline 2009 & 10 & 1 & - & - & 7 & 7 & 8 & 5 & 4 \\
\hline 2010 & 1 & 10 & - & - & - & 0 & 1 & 1 & 0 \\
\hline \multicolumn{10}{|l|}{ Site 2} \\
\hline 2008 & 1 & 0 & - & - & 1 & 1 & 1 & 1 & 1 \\
\hline 2009 & 1 & 0 & - & - & 0 & 0 & 1 & 1 & 1 \\
\hline 2010 & 1 & 0 & - & - & 0 & 1 & 1 & 1 & 1 \\
\hline 2011 & 1 & 0 & - & - & 0 & 0 & 1 & 1 & 1 \\
\hline 2009 & 2 & 2 & 2 & 1 & 0 & 0 & 0 & 0 & 0 \\
\hline 2010 & 3 & 1 & 2 & 2 & 1 & 2 & 3 & 0 & 1 \\
\hline 2011 & 2 & 2 & 2 & 2 & 2 & 0 & 1 & 1 & 1 \\
\hline 2012 & 2 & 2 & 2 & 2 & 0 & 0 & 0 & 0 & 2 \\
\hline
\end{tabular}

cial harvest) logged over 20 years earlier to promote diameter tree growth and increased forage production. This logged area was one of the most preferred and largest grazing sites in the entire allotment. Water developments in this area were not accessed by cattle as frequently as the stream because their location placed them outside the preferred grazing area when compared to the centrally located stream. It appeared that as long as abundant water is available, the location of the cattle is primarily determined by where the best grazing conditions exist.

Site 3 shows an opposite pattern when contrasted with Site 2. Collared cattle were found within $60 \mathrm{~m}(196.9 \mathrm{ft})$ of permanent streams in the early months of the grazing season (on this site, turn-out is in April rather than June as with Sites 1 and 2). Early in the season, areas deep in the canyons are warmer, and forage, which cattle use, is therefore more succulent and abundant. The grazing progression therefore starts in the lower elevation canyons adjacent to streams and progresses with the season up slopes to areas farther and farther from permanent streams. On Site 3, in three of the five years of the study, collared cows did not visit live streams in June, July, August, and September because they were grazing mountains and table lands where no accessible perennial streams exist.

Seasonal and Annual Intensity of Use of 30 and 60 Meter Stream/Riparian Buffers by Cattle. Tables 4 and 5 provide the relative percentage of collared cow positions in 30 $\mathrm{m}(98.4 \mathrm{ft})$ and $60 \mathrm{~m}$ (196.9 ft) buffers along perennial streams. This data is provided as a percentage of all logged data for the study site during each period. Table 4 is spatially more restrictive and therefore has somewhat lower values than table 5. Together they indicate the relative use of the perennial stream buffer by cattle on each site by year and month. Comparison of the data indicates that the near stream $30 \mathrm{~m}$ buffer is used slightly heavier than the adjacent, somewhat more distant band out to $60 \mathrm{~m}$. Also provided in these tables is the relative percentage of the site enclosed in the $30 \mathrm{~m}$ and $60 \mathrm{~m}$ buffers. These values can be used to determine the relative preference of the buffered area when contrasted with collared cow occupancy across the entire allotment. Site preference is calculated by dividing the percentage collared cow occupancy on a site, year, and month by the relative percentage of the pasture in that buffer. This generates an index (Krueger 1972; Stuth 1991) that can be used to indicate site preference.Values close to zero indicate avoidance, values near one are neutral in use, and values above one are preferred. Significant differences in use pattern during those months that collared cattle were present in all allotments were found between sites $(p<0.0001)$ and between years $(p=0.0009)$ with a significant site by year interaction $(p=0.0002)$. These differences appear to reflect landscape differences that impact management decisions and the subsequent livestock use of the different allotments.

Site 1 had relatively low collared cow presence on $30 \mathrm{~m}(98.4 \mathrm{ft})$ and $60 \mathrm{~m}(196.9$ $\mathrm{ft}$ ) buffers across most months of the year with the possible exception of July of 2011 (3.38\%) and September of 2012 (3.26\%) (tables 4 and 5). This may have been caused by higher demand for water or by close proximity of favored grazing locations by collared cattle to perennial streams. During 17 of the 24 months collared cattle were monitored on this allotment, cattle occupied the $30 \mathrm{~m}$ riparian buffer with less intensity $(0.74 \%)$ than the pasture as a whole $(1.08 \%)$.

Site 2 shows a fairly clear pattern of higher occupancy in riparian buffers during late summer than in June and July (tables 4 and 5). The highest absolute use was during August of 2012 (11.56\% within $30 \mathrm{~m}$ [98.4 $\mathrm{ft}], 16.71 \%$ within $60 \mathrm{~m}$ [196.9 ft]). High 
occupancy (RPI Index $\geq 3$ ) occurred in 8 of the 25 months cattle were monitored. Mean occupancy across all years by month for the $60 \mathrm{~m}$ buffer was $6.74 \%$ in August and $6.98 \%$ in September. This relatively high level of occupancy was expected because cattle were grazing a portion of allotment previously logged. These logged sites have higher production of herbaceous plants and straddled the perennial creek for a portion of its length. Because the stream is easily accessed from these favored grazing areas, we expected higher stream use.

As with cattle occupancy on stream reaches, Site 3 showed an opposite pattern to Site 2 with higher use earlier in the year. Stream/riparian areas on Site 3 were deep in canyons that were grazed in April and May where livestock entered this allotment. As the season progressed and forage became available at higher elevations, cattle migrated up the elevation gradient into areas that were devoid of permanent streams; thus, collared cows relied almost exclusively on water developments and other water sources (tables 4 and 5). There was no significant effect of year $(p=0.1205)$, but the effect of month was highly significant $(p=0.0002)$. April had higher stream use by collared cattle than May and both months were significantly different from June through October $(p=$ $0.05)$. Again, this is the result of the grazing system in place on this allotment, where the lower elevation, warmer ranges that are close to perennial streams are grazed in April and May. These areas generally lack off-stream water developments and cattle, and therefore have little option other than to water at the perennial stream. Only when animals were gathered in the autumn (November or later) and brought back to lower elevations did we again see occupancy in the $60 \mathrm{~m}(196.9 \mathrm{ft})$ stream buffer. This use pattern held for all five years of the study. We must note that this allotment has never been out of compliance with USFS standards for stream/riparian health in spite of this early use.

Intensity of Use by Collared Cattle on Perennial Streams. Being present along the stream does not indicate the relative intensity of the use by livestock at specific locations (i.e., a relatively heavy occupancy spread over a long reach could translate to moderate use per meter of stream). Likewise, relatively high levels of occupancy do not necessarily translate to riparian or stream bank degradation. For example, a stream flowing over

\section{Table 4}

Percentage of all recorded collared cattle positions found within a $30 \mathrm{~m}$ buffered area on either side of all perennial streams on the three study sites by year and month of the grazing season as a percentage of all recorded positions on the site. Most of the streams on these mountainous allotments are relatively narrow $(<3 \mathrm{~m})$ with ascending topography on either side, thus the o to $30 \mathrm{~m}$ buffer encompasses most riparian corridor areas. Across all sites and years cattle were found in the $30 \mathrm{~m}$ buffer on both sides of live streams $1.37 \%$ of the day, or slightly less than 20 minutes per day.

\begin{tabular}{lllllll}
\hline & \multicolumn{6}{c}{ Recorded collared cattle positions within a 30 m buffered area by year (\%) } \\
\cline { 2 - 7 } Site/month & $\mathbf{2 0 0 8}$ & $\mathbf{2 0 0 9}$ & $\mathbf{2 0 1 0}$ & $\mathbf{2 0 1 1}$ & $\mathbf{2 0 1 2}$ & All years \\
\hline Site 1 & & & & & & \\
June & 0.00 & 1.19 & NA* & 0.05 & 0.00 & 0.31 \\
July & 0.51 & 0.70 & 0.00 & 3.38 & 0.02 & 0.92 \\
Aug. & 0.99 & 0.70 & 0.02 & 1.92 & 0.08 & 0.74 \\
Sept. & 0.22 & 0.36 & 0.00 & 1.67 & 3.26 & 1.10 \\
Oct. & 1.21 & 0.58 & 0.00 & 1.21 & 0.00 & 0.60 \\
Season long & 0.55 & 0.68 & 0.01 & 1.98 & 0.50 & 0.74
\end{tabular}

Site 1 surface area of 30-m buffer on permanent streams $=1.08 \%$ of allotment

\begin{tabular}{lrrrrrr}
\hline Site 2 & & & & & & \\
June & 1.27 & 0.00 & 0.00 & 0.00 & 0.00 & 0.25 \\
July & 1.18 & 0.00 & 0.09 & 0.00 & 0.00 & 0.25 \\
Aug. & 5.94 & 2.76 & 4.65 & 1.15 & 11.56 & 5.21 \\
Sept. & 7.05 & 4.27 & 2.44 & 5.14 & 6.09 & 5.00 \\
Oct. & 0.58 & 1.47 & 1.01 & 4.51 & 2.20 & 1.95 \\
Season long & 3.55 & 1.62 & 1.84 & 1.66 & 4.03 & 2.54
\end{tabular}

Site 2 surface area of $30-\mathrm{m}$ buffer on permanent streams $=1.19 \%$ of allotment Site 3

$\begin{array}{lllllll}\text { Apr. } & 1.76 & 0.49 & 5.31 & 8.04 & 6.91 & 4.50 \\ \text { May } & 0.66 & 0.39 & 1.39 & 2.71 & 5.67 & 2.16 \\ \text { June } & 0.00 & 0.00 & 0.35 & 0.01 & 0.00 & 0.07 \\ \text { July } & 0.00 & 0.00 & 1.10 & 0.00 & 0.00 & 0.22 \\ \text { Aug. } & 0.00 & 0.00 & 0.01 & 0.00 & 0.00 & 0.00 \\ \text { Sept. } & 0.00 & 0.00 & 0.00 & 0.00 & 0.00 & 0.00 \\ \text { Oct. } & \mathrm{NA}^{*} & 0.00 & 0.01 & 0.00 & 0.50 & 0.13 \\ \text { Season long } & 0.46 & 0.08 & 0.73 & 1.09 & 1.95 & 0.86\end{array}$

Site 3 surface area of 30-m buffer on permanent streams $=1.65 \%$ of allotment

\begin{tabular}{lllllll}
\hline Grand total & 1.42 & 0.86 & 0.93 & 1.49 & 2.13 & 1.37
\end{tabular}

*Collared cattle were not present or did not log on the study allotment during this period.

bedrock with a rock-based approach could be used with little impact. Therefore, we endeavored to identify specific locations with frequent contact by collared cattle to better understand the effects of cattle presence on perennial streams. To quantify presence and identify specific areas of stream use, we constructed spatially explicit matrices with the individual counts of cow positions in gridded cells $(30 \mathrm{~m}$ by $30 \mathrm{~m}[98.4 \mathrm{ft}$ by $98.4 \mathrm{ft}]$ ) covering the landscape. This data layer could be viewed as a GIS map overlay. Individual cells retain the count values from the GPS collars, each of which represent approximately 5.3 minutes of occupancy of a collared cow. These raster maps and their derived isolines of occupancy at two hour intervals $(24,48,72,96,120$, etc.) were recorded on a "per hectare" basis. This process allowed us to identify both intensity of use and linear extent of cattle presence along streams (figure 1).

We first determined the proportion of each perennial stream that had little or no collared cattle presence by setting a rate of 24 collared cow positions ha ${ }^{-1}\left(10\right.$ positions $\left.\mathrm{ac}^{-1}\right)$ over the entire grazing season as a threshold. By this, we mean if a cell containing a perennial stream had less than $2 \mathrm{~h}$ occupancy $\mathrm{ha}^{-1}$ $\mathrm{y}^{-1}$, then that cell was considered below the occupation threshold. Obviously, 100 minus this value is the proportion of the stream that is occupied above the 24 GPS position threshold (table 6). 


\section{Table 5}

Percentage of all recorded collared cattle positions found within a $60 \mathrm{~m}$ buffered area on either side of all perennial streams on each of the three study sites by year and month of the grazing season as a percentage of all recorded positions on the site. Most of the streams on these mountainous allotments are relatively narrow ( $13 \mathrm{~m}$ ) with ascending topography on either side, thus the $60 \mathrm{~m}$ buffer represents a wide riparian corridor. Across all sites and years cattle were found in the $60 \mathrm{~m}$ buffer on both sides of live streams $2.47 \%$ of the day or 35.6 minutes per day. When contrasted with data in table 4 , the o to $30 \mathrm{~m}$ zone is used approximately 3.9 minutes more per day than the 30 to $60 \mathrm{~m}$ zone.

\begin{tabular}{lcccccc}
\hline & \multicolumn{6}{c}{ Recorded collared cattle positions within a $\mathbf{6 0} \mathbf{~ m}$ buffered area by year (\%) } \\
\cline { 2 - 7 } Site/month & $\mathbf{2 0 0 8}$ & $\mathbf{2 0 0 9}$ & $\mathbf{2 0 1 0}$ & $\mathbf{2 0 1 1}$ & $\mathbf{2 0 1 2}$ & All years \\
\hline Site 1 & & & & & & \\
June & 0.02 & 2.40 & NA* & 0.15 & 0.93 & 0.88 \\
July & 0.92 & 1.14 & 0.07 & 6.01 & 1.38 & 1.90 \\
Aug. & 2.21 & 1.09 & 0.84 & 3.59 & 2.49 & 2.04 \\
Sept. & 0.85 & 0.74 & 0.80 & 2.88 & 6.89 & 2.43 \\
Oct. & 2.14 & 0.91 & 1.80 & 1.95 & 0.00 & 1.36 \\
Season long & 1.21 & 1.18 & 0.71 & 3.54 & 2.41 & 1.81
\end{tabular}

Site 1 surface area of $60-\mathrm{m}$ buffer on permanent streams $=2.15 \%$ of allotment Site 2

$\begin{array}{lrrrrrr}\text { June } & 2.08 & 0.00 & 0.00 & 0.00 & 0.00 & 0.42 \\ \text { July } & 2.19 & 0.00 & 0.14 & 0.00 & 0.00 & 0.47 \\ \text { Aug. } & 8.16 & 4.13 & 6.67 & 1.62 & 16.71 & 7.46 \\ \text { Sept. } & 10.56 & 6.10 & 3.95 & 7.53 & 9.66 & 7.56 \\ \text { Oct. } & 1.06 & 2.77 & 1.44 & 8.17 & 3.94 & 3.48 \\ \text { Season long } & 5.29 & 2.44 & 2.74 & 2.52 & 6.11 & 3.82\end{array}$

Site 2 surface area of $60-\mathrm{m}$ buffer on permanent streams $=2.38 \%$ of allotment Site 3

$\begin{array}{lcrrrrr}\text { Apr. } & 4.93 & 1.33 & 10.59 & 17.20 & 14.34 & 9.68 \\ \text { May } & 1.77 & 0.90 & 2.80 & 5.88 & 10.88 & 4.45 \\ \text { June } & 0.00 & 0.00 & 0.72 & 0.03 & 0.00 & 0.15 \\ \text { July } & 0.00 & 0.00 & 1.62 & 0.00 & 0.00 & 0.32 \\ \text { Aug. } & 0.00 & 0.00 & 0.01 & 0.01 & 0.00 & 0.00 \\ \text { Sept. } & 0.00 & 0.00 & 0.00 & 0.01 & 0.00 & 0.00 \\ \text { Oct. } & \mathrm{NA} & 0.00 & 0.09 & 0.01 & 0.95 & 0.26 \\ \text { Season long } & 1.26 & 0.19 & 1.39 & 2.35 & 3.85 & 1.81\end{array}$

Site 3 surface area of $60-\mathrm{m}$ buffer on permanent streams $=3.33 \%$ of allotment

\begin{tabular}{lllllll}
\hline Grand total & 2.46 & 1.37 & 1.67 & 2.77 & 4.09 & 2.47 \\
\hline *Collared cattle were not present or did not log on the study allotment during this period.
\end{tabular}

As can be seen in table 6, some streams have no portions of their length that exceeded the minimal occupancy threshold for the year. For example, perennial streams 2 and 4 on Site 1 had no portion of their length that exceeded the approximately $2 \mathrm{~h}$ $\mathrm{y}^{-1}$ threshold over the duration of the five year study. When viewing all streams on the Site 1 allotment in aggregate, $6 \%$ of the total stream length was above the use threshold; thus, $94 \%$ of the total stream length had no or very low occurrence of collared cattle. During 2009 a substantially larger proportion of the perennial stream length on Site 1 had cattle occupancy above the threshold than in other years (table 6). Perennial streams 8 and 9 had $27.1 .3 \%$ and $19.6 \%$ of their length occupied by collared cattle in 2009. In this year cattle were using the stream corridor to move from lower to higher elevation grazing areas. Across all years studied, perennial streams 1 and 10 on Site 1 received more extensive use across a larger portion of their length followed by stream 9 (table 6). This resulted from the grazing pathways employed to move animals through the allotment and the rotational system.

Site 2 varied between $69.6 \%$ and $82.6 \%$ of the stream corridor at no or very low occupancy. On average across the five years of the study, $25.9 \%$ of the stream length was occupied above the threshold (table 6). The single, long creek on this site is paralleled by roads within $60 \mathrm{~m}$ (196.9 ft) on one side of the stream or the other (or both) over nearly its entire length as it traverses the allotment. Of the $24.3 \mathrm{~km}$ (15.1 mi) of stream, only 1.1 $\mathrm{km}(0.7 \mathrm{mi})$ has a roadway farther than 100 $\mathrm{m}(328 \mathrm{ft})$ from the thalweg. Because humans, cattle, and wildlife use the roads for movement, it is not surprising that this creek would have more interactions along its length. This juxtaposition of stream and road unfortunately generates confusion of purpose because cow positions can result from either travel on the road or from stream/riparian usage. Cattle, therefore, may not have independently chosen to be near the stream.

The relative percentage of total stream length used above the threshold by cattle on Site 3 shows a similar pattern to Site 1 (table 6). On Site 3 the effect of year was not significant $(p=0.3141)$, nor was the effect of perennial stream $(p=0.0660)$. The entire length of two of the streams were unused by livestock over the five years of the study, and the two other streams were occupied along $12.6 \%$ and $25.5 \%$ of their length (table 6).

In summary, streams and their associated buffer areas vary substantially in relative use by cattle. Some perennial streams on these allotments were not used, while others were frequently used. Large percentages of the length of those streams that were visited by collared cattle had minimal occupancy rates, as would be expected in mountainous environments where access to the stream may be blocked by topography, shrubs and brush, steep banks, and other obstacles. Pathways from favorite grazing areas to the streams would also be expected to funnel animals to specific locations for watering. In addition, roadways and jeep trails that parallel the stream affect cattle travel routes within the allotments and influence where along the stream cattle water.

Figure 1 is a graphical representation of the relative occupancy of the single stream on Site 2 by linear distance as it traverses the grazing allotment. We can visually see locations where collared cattle congregated and long stretches where there was little interaction with the stream. Those areas of high use can be monitored for condition and trend of stream/riparian vegetation, stream bank stability, and other factors related to stream and riparian health. We should again note that prior to and throughout this experiment none of the allotments studied have been out 
of compliance with USFS regulations concerning riparian health.

When we examined the relative length of perennial streams utilized at different intensities such as $24,48,72,96$, and 120 points $\mathrm{ha}^{-1}$ $\mathrm{y}^{-1}\left(10,19,29,39\right.$, and 49 positions $\left.\mathrm{ac}^{-1} \mathrm{yr}^{-1}\right)$, we found a curvilinear relationship between the proportion of the stream length occupied $(y)$ and the hours of occupancy $(x)$ (or the number of cow positions logged). This relationship was different between sites $(p<$ $0.0001)$, but not between years $(p=0.5230)$.

On Site 1, which had the most dispersed use of perennial streams by livestock, only $5 \%$ of the total stream length on the allotment had 24 collared cow positions ha ${ }^{-1} \mathrm{y}^{-1}$ (10 positions $\mathrm{ac}^{-1} \mathrm{yr}^{-1}$ ) and the relationship to increasing cattle concentration was $\hat{Y}=$ $-0.036 \ln (x)+0.0811$ and the $R^{2}=0.6696$.

Site 2 had a relatively high linear use of perennial streams. Twenty-five percent of the

\section{Figure 1}

The number of collared cattle positions (CCP) logged per hectare plotted against the length of the creek as it traverses Site $\mathbf{2}$ for the $\mathbf{2 0 1 2}$ grazing season. The X-axis is the distance from where the stream enters the allotment to where it exits the allotment, and the $\mathrm{Y}$-axis is the number of cattle positions logged over the entire grazing season. Values are reported as number per hectare. Because locations are taken at approximately five minute intervals, duration of occupancy can be inferred as $125 \mathrm{CCP} \approx 10.41$ hours of occupancy ha-1 $250 \mathrm{CCP} \approx 20.83$ hours of occupancy ha ${ }^{-1}$, and $500 \mathrm{CCP} \approx 41.66$ hours of occupancy ha- ${ }^{-1}$.

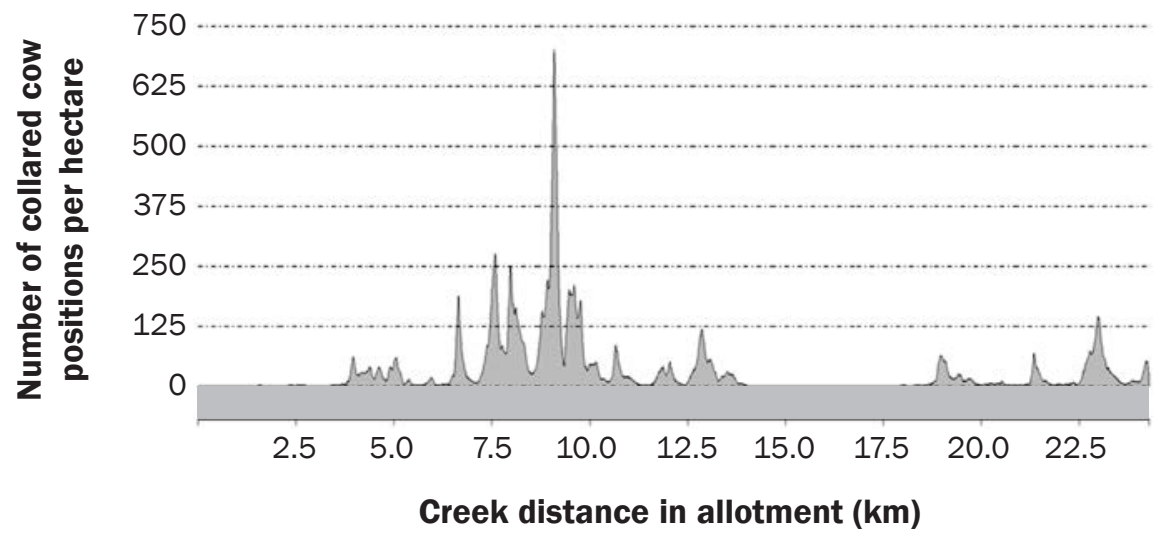

\section{Table 6}

Relative percentage of each stream length that was occupied by collared cattle at a rate greater than 24 GPS positions per hectare. The provided percentages of each perennial stream length had more than 24 cow positions per hectare summed over the entire grazing season for that year. Five year means followed by the same lowercase letter are not significantly different at $p=0.05$.

\begin{tabular}{|c|c|c|c|c|c|c|c|}
\hline \multirow[b]{2}{*}{ Site/perennial stream } & \multirow{2}{*}{$\begin{array}{l}\text { Stream } \\
\text { length }(\mathrm{m})\end{array}$} & 2008 & 2009 & 2010 & 2011 & 2012 & Five year mean \\
\hline & & \multicolumn{6}{|c|}{ Cattle occupancy > 24 points ha ${ }^{-1}$ (\% of stream length) } \\
\hline \multicolumn{8}{|l|}{ Site 1} \\
\hline Perennial Stream 1 & 7,876 & 25.7 & 15.0 & 0.0 & 62.1 & 10.40 & 22.6ab \\
\hline Perennial Stream 2 & 3,174 & 0.0 & 0.0 & 0.0 & 0.0 & 0.0 & $0.0 \mathrm{c}$ \\
\hline Perennial Stream 3 & 1,214 & 0.0 & 7.4 & 0.0 & 0.0 & 0.0 & $1.5 c$ \\
\hline Perennial Stream 4 & 867 & 0.0 & 0.0 & 0.0 & 0.0 & 0.0 & $0.0 \mathrm{c}$ \\
\hline Perennial Stream 5 & 1,047 & 0.0 & 4.4 & 0.0 & 0.0 & 0.0 & $0.9 c$ \\
\hline Perennial Stream 6 & 2,302 & 0.0 & 14.9 & 0.0 & 0.0 & 0.0 & $3.0 c$ \\
\hline Perennial Stream 7 & 10,799 & 0.0 & 5.4 & 0.0 & 0.0 & 0.0 & $1.1 \mathrm{c}$ \\
\hline Perennial Stream 8 & $2,034.4$ & 0.0 & 27.1 & 0.0 & 0.0 & 0.0 & $5.4 c$ \\
\hline Perennial Stream 9 & $3,409.1$ & 0.0 & 19.6 & 0.0 & 12.8 & 0.0 & $6.5 b c$ \\
\hline Perennial Stream 10 & $2,116.2$ & 8.7 & 8.9 & 0.0 & 89.3 & 18.0 & $25.0 a$ \\
\hline Perennial Stream 11 & 4,345 & 0.0 & 0.0 & 0.0 & 0.0 & 0.0 & $0.0 c$ \\
\hline Mean & & & & & & & 6.0 \\
\hline \multicolumn{8}{|l|}{ Site 2} \\
\hline Perennial Stream 1 & 24,280 & 30.4 & 26.4 & 26.2 & 17.4 & 29.1 & 25.9 \\
\hline \multicolumn{8}{|l|}{ Site 3} \\
\hline Perennial Stream 1 & 4,760 & 0.0 & 0.0 & 0.0 & 0.0 & 0.0 & $0.0 b$ \\
\hline Perennial Stream 2 & 3,707 & 0.0 & 0.0 & 55.2 & 0.0 & 7.7 & $12.6 a b$ \\
\hline Perennial Stream 3 & 17,728 & 13.0 & 4.9 & 35.4 & 58.0 & 16.4 & $25.5 a$ \\
\hline Perennial Stream 4 & 1,282 & 0.0 & 0.0 & 0.0 & 0.0 & 0.0 & $0.0 b$ \\
\hline Mean & & & & & & & 9.5 \\
\hline
\end{tabular}


perennial stream length had $2 \mathrm{~h}$ occupancy $\mathrm{ha}^{-1} \mathrm{y}^{-1}$, but the linear distance impacted drops off quickly to $10 \%$ of the perennial stream length with a threshold of six hours of occupancy (72 collared cow positions ha ${ }^{-1}$ $\mathrm{y}^{-1}\left[29\right.$ positions $\left.\mathrm{ac}^{-1} \mathrm{yr}^{-1}\right]$ ). The relationship on this allotment was $\hat{Y}=-0.133 \ln (x)+$ 0.3421 with a $R^{2}=0.8143$. This again shows the influence of close proximity of roads to the single, long creek and the relatively easy dispersal of livestock along its length.

Site 3 had two years with greater perennial stream length use and three years with a shorter length of perennial stream use, more similar to Site 1. Years were significantly different $(p<0.0001)$, as well as hours of collared cow occupancy $(p=0.0004)$. The years 2010 and 2011 were significantly different from 2008, 2009, and 2012, which were all similar. Because of this dichotomy (figure 2), the relationship $y=-0.078 \ln (x)+$ 0.232 had a relatively low correlation coefficient $\left(R^{2}=0.1865\right)$.

We would expect that different locations along the course of the stream would have different tolerances to cattle presence. Some locations could be very resilient because of topographic approach, surface (rock, cobbles, sand, etc.), and vegetative characteristics. Other locations might be more easily impacted because of the presence of delicate plants that cannot tolerate even light use, or unstable stream bank characteristics. In any case, much of the stream/riparian system had low collared cattle density across the five years of the study, and as the tolerable occupancy threshold increases, the relative length of the stream visited at threshold rates drops in a curvilinear fashion (figure 2).

\section{Summary and Conclusions}

A number of insights can be gained from knowledge of the distributional pattern of cattle along mountain streams. The first is that, under the USFS grazing plans in place on these sites, substantial proportions of the stream and associated riparian system are infrequently visited by cattle. As livestock move through these allotments the specific streams and stream reaches used changes, so a location frequently used in one portion of the year may be totally unused in other periods. Federal managers and rancher permittees have known this for years and the grazing systems in place employ this "rotational grazing" or "graze and move" pattern to encourage plant and riparian ecosystem health.

\section{Figure 2}

Relationship of the proportion of the stream occupied by collared cattle at various levels for Site 3. Years 2010 and 2011 had substantially more length of the perennial stream occupied by collared cattle than did 2008, 2009, or 2012. Annual regression lines followed by the same alphabetic superscript are not significantly different at $p=0.05$. Occupancy of the stream/riparian buffer is highest in those years when cattle remain in the lowlands longer. In some years, cattle are intentionally herded onto lower elevation benches that closely parallel the stream in these canyons because forage is abundant.

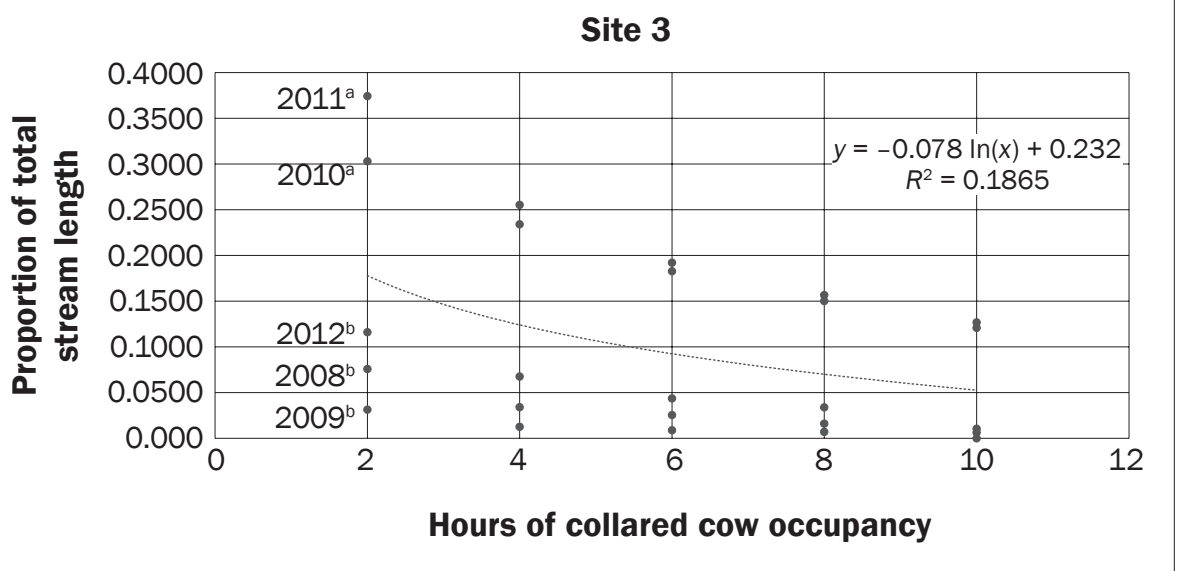

Cattle use the road and trail networks for travel to and from favored stream watering sites, and stream access is frequently limited to locations that afford a gentle, sloped approach to the stream with a relatively firm land surface. Once the principal watering areas or sites are identified, it is much easier to monitor allotments for change in ecological condition. It is also easier to identify improvements to lessen negative effects on stream or water quality, such as rocked approaches to the stream or off stream watering tanks or troughs (Wyman et al. 2006).

Since none of the allotments were determined to be out of compliance with USFS standards for riparian health, we assume that these levels of interaction are acceptable under current guidelines. Thus, the information collected in this study suggests that cattle can graze these mountainous rangelands in a sustainable fashion.

\section{Acknowledgements}

The authors gratefully acknowledge the following organizations and individuals for funding, cooperation, and technical and logistic support: (1) USDA National Institute of Food and Agriculture ("Developing an Adaptive Management System and its Components to Address Effects of Gray Wolf Reintroduction on Ecosystem Services" Agency Number: 2010-85101-20512 and "Development Of Planning and Monitoring Elements of an Adaptive Management System for Wolf-Livestock Relations" NIFA Project No. 536213610-009-06R), (2) Oregon Beef Council, (3) Oregon State University/Oregon Agricultural Experiment Station,
(4) USDA Agricultural Research Service, (5) University of Idaho, (6) International Center for Agricultural Research in the Dry Areas (ICARDA), and (7) farm and ranch families on the research sites. Animals were handled in accordance with Oregon State University animal handling protocols under permit ACUP \# 4555.

\section{References}

Anderson, E.W., M.M. Borman, and W.C. Krueger. 1998. The ecological provinces of Oregon, a treatise on the basic ecological geography of the state. Oregon Agricultural Experiment Station SR 990. Crook County, OR: Oregon State University Department.

Armour, C., D. Duff, and W. Elmore. 1994. The effects of livestock grazing on western riparian and stream ecosystem. Fisheries 19(9):9-12.

Bailey, D.W., J.E. Gross, E.A. Laca, L.R. Rittenhouse, M.B. Coughenour, D.M. Swift, and P.L. Sims. 1996. Mechanisms that result in large herbivore grazing distribution patterns. Journal of Range Management 49:386-400.

Bailey, W.D., H.C. Van Wagoner, R. Weinmeister, and D. Jensen. 2008. Evaluation of low-stress herding and supplement placement for managing cattle grazing in riparian and upland areas. Rangeland Ecology and Management 61(1):26-37.

Bryant, F.T., R.E. Blaser, and J.R. Peterson. 1982. Effect of trampling by cattle on bluegrass yield and soil compaction of a Meadowville Loam. Agronomy Journal 64:331-334.

Bryant, L.D. 1982. Response of livestock to riparian zone exclusion. Journal of Range Management 35(6):780-785. 
Burt, W.H. 1943. Territoriality and home range concepts as applied to mammals. Journal of Mammalogy 24(3):346-352.

Clark, P.E., D.E. Johnson, M.A. Kniep, P. Jermann, B. Huttash, A. Wood, M. Johnson, C. McGillivan, and K. Titus. 2006. An advanced, low-cost, GPS-based animal tracking system. Rangeland Ecology and Management 59:334-340.

Cook, C.W. 1966. Factors affecting utilization of mountain slopes by cattle. Journal of Range Management 19:200-204.

Coughenour, M.B. 1991. Spatial components of plantherbivore interactions in pastoral, ranching and native ungulate ecosystems. Journal of Range Management 44:530-542.

Ganskopp, D. 2001. Manipulating cattle distribution with salt and water in large arid-land patures: A GPS/ GIS assessment. Applied Animal Behaviour Science 73:251-263.

Ganskopp, D., R. Cruz, and D.E. Johnson. 2000. Least-effort pathways? A GIS analysis of livestock trails in rugged terrain. Applied Animal Behaviour Science 68:179-190.

Ganskopp, D., and M. Vavra. 1987. Slope use by cattle, feral horses, deer, and bighorn sheep. Northwest Science 61:74-81.

Gillen, R.L., W.C. Krueger, and R.F. Miller. 1984. Cattle distribution on mountain rangeland in northeastern Oregon. Journal of Range Management 37(6):549-553.

Hall, F.C. 1973. Plant communities of the Blue Mountains in eastern Oregon and southeastern Washington. R6 Area Guide 3-1. Portland, OR: USDA Forest Service, Pacific Northwest Region.

Harris, N.R., D.E. Johnson, M.R. George, and N.K. McDougald. 2002. The effect of topography, vegetation, and weather on cattle distribution at the San Joaquin Experimental Range, California. USDA Forest Service General Technical Report. PSW-GTR-184:53-63. http://www.fs.fed.us/psw/publications/documents/ psw_gtr184/005_HarrisNorm.pdf.

Johnson, D.D., and D.C. Ganskopp. 2008. GPS Collar sampling frequency: Effects on measures of resource use. Rangeland Ecology and Management 61:226-231.

Johnson, D.E., P.E. Clark, L.L. Larson, M. Louhaichi, and J. Williams. 2012. Beef Council Report: Wolf Cattle Interaction Study. Research Report to Oregon Beef Council. Department of Rangeland Ecology and Management, OR: Oregon State University. http:// extension.oregonstate.edu/wallowa/sites/default/ files/2012_october_22_oregon_beef_council_report_ final_d.pdf.

Kauffman, J.B., W.C. Krueger, and M.Vavra. 1983. Impacts of cattle grazing streambanks in northeastern Oregon. Journal of Range Management 36:683-685.

Kie, J.G., J. Matthiopoulos, J. Fieberg, R.A. Powell, F. Cagnacci, M.S. Mitchell, J.M. Gaillard, and P.R. Moorcroft. 2010. The home-range concept: Are traditional estimators still relevant with modern telemetry technology? Philosophical Transactions of the Royal Society B 365:2221-2231.

Kluever, B.M., L.D. Howery, S.W. Breck, and D.L. Bergman. 2009. Predator and Heterospecific Stimuli Alter Behavior in Cattle. Behavioural Processes 81:85-91.

Krueger, W.C. 1972. Evaluating animal forage preference. Journal of Range Management 25:471-475.

Liu, T., A.R. Green, L.F. Rodríguez, B.C. Ramirez, and D.W. Shike. 2015. Effects of number of animals monitored on representations of cattle group movement characteristics and spatial occupancy. PlOS ONE 10(2):e0113117.

McInnis, M.L., and J.D. McIver. 2009. Timing of cattle grazing alters impacts on stream banks in an Oregon mountain watershed. Journal of Soil and Water Conservation 64(6):394-399, doi:10.2489/ jswc.64.6.394.

Plowman, B.W., L.M. Conner, M.J. Chamberlain, B.D Leopold, and L.W. Burger Jr. 2006. Annual dynamics of bobcat (Lynx rufus) home range and core areas in Mississippi. American Midland Naturalist 156:386-393.

Powel, R.A. 1987. Black bear home range overlap in North Carolina and the concept of home range applied to black bears. International Conference on Bear Research and Management 7:235-242.

PRISM Climate Group. 2014. 30-Year Normals. http:// www.prism.oregonstate.edu/normals/.

Roath, L.R., and W.C. Krueger. 1982. Cattle grazing and behavior on a forested range. Journal of Range Management 35:332-338.

Statgraphics Centurion XVI. 2010. STATGRAPHICS Centurion XVI User Manual. StatPoint Technologies, Inc. www.statgraphics.com.

StreamNet. 2016. Maps and GIS Data. http://www. streamnet.org/data/interactive-maps-and-gis-data/.

Stuth, J.W. 1991. Foraging Behavior. In Grazing Management: An Ecological Perspective, eds. R.K. Heitschmidt, and J.W. Stuth. Portland, Oregon: Timber Press. http://cnrit.tamu.edu/rlem/textbook/ textbook-fr.html.

US GAO (US General Accounting Office). 1988. Public rangelands: Some riparian areas restored by widespread improvement will be slow. GAO/RCED-88-105. http://www.gao.gov/assets/150/146590.pdf.

USDA: Agriculture Handbook 296. 2006. Major Land Resource Regions Custom Report.

Wagnon, K.A. 1968. Use of different classes of range land by cattle. California Agricultural Experiment Station Bulletin 838. Berkeley, CA: University of California, Berkeley

Wilson, K.D. 2010. Landscape occupancy by free ranging cattle in Northeast Oregon. Master's thesis, Oregon State University.

Wyman, S., D. Bailey, M. Borman, S. Cote, J. Eisner, W. Elmore, B. Leinard, S. Leonard, F. Reed, S. Swanson, L. Van Riper, T. Westfall, R. Wiley, and A. Winward. 2006. Riparian area management: Grazing management processes and strategies for riparianwetland areas. Technical Reference 1737-20. BLM/
ST/ST-06/002+1737. U.S. http://www.blm.gov/or/ programs/nrst/files/Final\%20TR\%201737-20.pdf. 